Syntax Fusion : Jurnal Nasional Indonesia

e-ISSN : 2775-4440

Vol. 1, No. 9, September 2021

\title{
UPAYA MENINGKATKAN HASIL BELAJAR SISWA KELAS VI SD NEGERI JANGGI DALAM MATERI MEMBANDINGKAN SIFAT MENGHANTAR PANAS
}

\section{Kulman Duwe}

SD Negeri Janggi

Email: kulmanduwe70@gmail.com

\begin{abstract}
Abstrak
Penelitian ini bertujuan untuk meningkatkan prestasi belajar saintifik siswa dengan membandingkan konsep sifat konduktivitas termal berbagai benda. Selain itu juga mengubah pembelajaran IPA yang semula masih berpusat pada guru dan disajikan secara lisan, serta menjadikan siswa aktif dengan memberikan kesempatan bereksperimen. Metode yang digunakan dalam penelitian ini adalah penelitian tindakan kelas. Penelitian ini dilakukan dalam 2 siklus dengan menggunakan metode eksperimen. Setiap siklus terdiri dari 2 kali pertemuan. Setiap siklus meliputi tahap perencanaan, tahap pelaksanaan, tahap observasi dan refleksi. Penelitian ini dilaksanakan pada siswa kelas VI SD Negeri Janggi dari bulan Agustus 2017 sampai dengan Oktober 2017 pada tahun pelajaran 2017/2018. Jumlah siswa yang diamati dalam penelitian ini adalah 23 siswa. Dari penelitian yang dilakukan, penerapan metode eksperimen dapat meningkatkan hasil belajar siswa MI Ruhul Ulum. Hal ini terlihat pada kondisi awal sebelum pelaksanaan tindakan, nilai rata-rata siswa 39,35 dan nilai ketuntasan 8,70\%. Nilai rata-rata kelas pada siklus I adalah 68,48, dan tingkat ketuntasan 60,87\% yang tidak mencapai tingkat ketuntasan pembelajaran siklus I. Pada siklus II, nilai rata-rata kategori ini adalah 80,65, dan tingkat ketuntasannya adalah 91,30\%. Pada siklus II pembelajaran selesai dan nilai KKM konsep adalah 65. Aktivitas guru pada siklus I tergolong baik, dengan persentase 73,6\%. Pada siklus II persentasenya meningkat menjadi $90 \%$ dan termasuk kategori sangat baik. Aktivitas siswa meningkat dari kategori sedang pada siklus I dengan persentase 67,5 menjadi kategori sangat baik, dan persentase pada siklus II sebesar $90 \%$.
\end{abstract}

Kata Kunci: Hasil Belajar, Metode Eksperimen, IPA

\section{Pendahuluan}

Pendidikan sangat erat kaitannya dengan perkembangan suatu negara. Pendidikan yang dapat mendukung perkembangan masa depan adalah pendidikan yang dapat mengembangkan potensi peserta didik agar tenaga yang terkait dapat menghadapi 
dan memecahkan sendiri permasalahan hidupnya. Tujuan utama pendidikan adalah mempersiapkan masa depan umat manusia agar dapat menjalani kehidupan yang lebih sejahtera, baik sebagai individu maupun sebagai warga masyarakat yang berguna bagi pembangunan di masa depan. Perkembangan pembangunan selalu menyesuaikan dengan tantangan zaman yang tidak dapat diprediksi, sehingga pendidikan selalu menghadapi masalah-masalah baru.

Masalah yang dihadapi dunia pendidikan begitu luas sehingga perlu dirumuskan masalah pendidikan sebagai pedoman bagi pendidik dalam melaksanakan tugasnya. Salah satu masalah yang sering diabaikan dalam pendidikan adalah penerapan metode pembelajaran yang inovatif di sekolah. Metode pembelajaran adalah langkah-langkah dari semua rencana dan prosedur serta kegiatan pembelajaran, termasuk bagaimana melakukan penilaian. Metode pembelajaran merupakan bagian dari strategi pembelajaran.Fungsi metode pembelajaran adalah menunjukkan, menggambarkan, memberi contoh dan memberikan latihan kepada siswa untuk mencapai tujuan tertentu, namun tidak setiap metode pembelajaran cocok untuk mencapai tujuan pembelajaran tertentu.

Penggunaan metode yang benar juga akan menentukan efektifitas dan efisiensi pembelajaran. Pembelajaran perlu dilakukan melalui sedikit ceramah dan pendekatan yang berpusat pada guru, dengan lebih menekankan pada interaksi siswa. Pada kenyataannya guru saat ini telah menerapkan metode pembelajaran dalam setiap proses belajar mengajar, namun seringkali banyak terjadi kesalahan dalam penerapan dan pemilihan metode. Wujud dari kesalahan tersebut adalah ketidaksesuaian metode mata pelajaran, yang membuat siswa tidak dapat memahami materi yang diberikan oleh guru sehingga menyebabkan rendahnya prestasi belajar siswa.

Penelitian berdasarkan dokumen, wawancara dan observasi yang diperoleh peneliti di SD Negeri Janggi, Kecamatan Kalauguara, Kabupaten Barito Selatan. Ditemukan bahwa hasil belajar siswa pada materi yang membandingkan karakteristik konduktivitas termal berbagai benda masih lebih rendah dari nilai KKM sebesar 59, dan nilai KKM konsep sebesar 65. Konduktivitas termal dari berbagai objek. Pada materi yang disampaikan secara lisan oleh guru melalui kegiatan ceramah dan berorientasi pada buku teks, partisipasi siswa sangat minim, karena siswa hanya melakukan kegiatan seperti duduk, diam, mendengarkan, mencatat, dan menghafal. Guru jarang menggunakan media atau alat peraga ilmiah, juga tidak digunakan untuk membiarkan siswa berpartisipasi dalam percobaan untuk membandingkan sifat-sifat kapasitas konduksi panas dari berbagai benda. Proses pembelajaran seperti ini bersifat monoton dan membosankan, mudah membuat siswa merasa bosan, membuat siswa menjadi pasif, dan mengakibatkan rendahnya prestasi belajar siswa.

Cara lain untuk meningkatkan hasil belajar siswa dan memungkinkan siswa belajar dengan cara terbaik adalah dengan menggunakan metode eksperimen. Metode eksperimen menurut Djamarah adalah suatu cara penyajian mata kuliah dimana mahasiswa bereksperimen dengan mengalami sendiri sesuatu

terpelajar. Dalam proses belajar mengajar metode eksperimen, siswa mendapat 
kesempatan untuk mengalami atau melakukannya sendiri, mengikuti suatu proses, dan mengamati objek, keadaan atau proses suatu hal.

Konsep membandingkan konduktivitas termal berbagai benda dalam IPA merupakan salah satu konsep pembelajaran yang dapat dipelajari melalui metode eksperimen. Dalam konsep ini guru tidak cukup memberikan penjelasan langsung, siswa juga harus berlatih atau menguji sifat-sifat konduktivitas termal dengan menggunakan benda-benda yang sering ditemui dalam kehidupan sehari-hari. Bendabenda tersebut terbuat dari berbagai bahan yaitu konduktor dan isolator. Bahan konduktor dapat menghantarkan panas, tetapi bahan isolator tidak dapat menghantarkan panas.Siswa dapat menggunakan eksperimen sendiri untuk memahami dan membuktikan keaslian konsep, serta menarik kesimpulan dari metode.

\section{Metode Penelitian}

Lokasi penelitian bertempat di SD Negeri Janggi Kecamatan Karau Kuala Kabupaten Barito Selatan yang beralamat di Desa Janggi. Adapun waktu penelitian dilaksanakan pada bulan Agustus - Oktober 2017,semester ganjil tahun pelajaran 2017/2018.

Metode yang digunakan dalam penelitian tindakan kelas ini adalah penelitian tindakan kelas kolaboratif, yaitu suatu kegiatan yang dilakukan oleh guru atau dengan orang lain (kerjasama) untuk memperbaiki atau meningkatkan kualitas proses pembelajaran di kelas. Penelitian ini dilaksanakan dalam siklus, dan setiap siklus meliputi 4 tahap, yaitu perencanaan pembelajaran saintifik dengan metode eksperimen, pelaksanaan pembelajaran saintifik dengan metode eksperimen, dan observasi serta refleksi pembelajaran. Sesuai dengan permasalahan atau kendala yang ditemukan dalam proses penelitian, maka penelitian ini terdiri dari beberapa siklus. Jika kriteria keberhasilan tidak terpenuhi, maka proses pembelajaran akan dilanjutkan pada siklus berikutnya. Apabila kriteria berhasil tercapai maka pengulangan akan berhenti yaitu kelas telah mencapai 90\% ketuntasan belajar, dan setiap siswa memiliki nilai KKM 65.

Subyek penelitian ini adalah siswa kelas VI SD Negeri Janggi Kecamatan Kalauguara Kabupaten Barito Selatan dengan jumlah siswa tahun ganjil tahun pelajaran 2017/2018 sebanyak 23 siswa..

Tahap intervensi tidankan yang akan dilakukan peneliti dalam penelitian adalah sebagai berikut : 
Tabel 3.1 Tahapan Intervensi Tindakan

Tahapan

\begin{tabular}{l} 
Terdapat masalah \\
\hline $\begin{array}{c}\text { Observasi kegiatan } \\
\text { Pembelajaran }\end{array}$ \\
Incara dengan guru IPA \\
kelas VI \\
\hline Wawancara dengan siswa
\end{tabular}

Dalam pembelajaran IPA materi membandingkan sifat kemampuan menghantar panas dari berbagai benda, siswa hanya melakukan kegiatan mencatat, mendengar, menghafal dan tidak dilibatkan dalam melakukan percobaan sehingga dalam proses pembelajaran siswa menjadi pasif dan mengalami

kebosanan.

\begin{tabular}{ll}
\hline Diagnosa & Metode eksperimen dapat diterapkan untuk \\
& meningkatkan hasil belajar IPA siswa pada materi \\
& membandingkan sifat kemampuan menghantar panas \\
& dari berbagai benda.
\end{tabular}


Upaya Meningkatkan Hasil Belajar Siswa Kelas VI Sd Negeri Janggi Dalam Materi Membandingkan Sifat Menghantar Panas

\begin{tabular}{ll}
\hline Tahap Perencanaan & Menyusun perangkat pembelajaran yang akan \\
diterapkan dalam pembelajaran pada materi & membandingkan sifat kemampuan menghantar panas \\
dari berbagai benda dengan metode eksperimen & Membuat lembar kerja siswa \\
& Membuat lembar observasi guru dan siswa dalam \\
proses pembelajaran & Membuat instrument tes \\
Melakukan uji coba instrumen \\
Melakukan uji validitas, reliabilitas menggunakan \\
Software Anates \\
Menyiapkan sumber belajar
\end{tabular}

\begin{tabular}{ll}
\hline Tahap Pelaksanaan & Melaksanakan pembelajaran sesuai dengan \\
\hline $\begin{array}{l}\text { perangkat pembelajaran yang akan diterapkan dalam } \\
\text { pembelajaran pada materi membandingkan sifat } \\
\text { kemampuan menghantar panas dari berbagai } \\
\text { benda dengan metode eksperimen }\end{array}$ \\
\hline Pengamatan & $\begin{array}{l}\text { Melaksanakan pretest, melaksanakan postest dan } \\
\text { penilaian LKS }\end{array}$ \\
\hline Refleksi & Mengolah data, refleksi untuk siklus II
\end{tabular}

Siklus II

Penulisan Laporan Penelitian

Jenis data antara lain data kualitatif dan data kuantitatif. Berikut penjelasannya.

1. Data Kualitatif

Data kualitatif adalah data yang diujudkan dalam kata keadaan atau kata sifat. Data kualitatif ini data berhubungan dengan kategorisasi, karakteristik berwujud pertanyaan atau berupa kata-kata.

\section{Data Kuantitatif}

Data kuantitatif yaitu data yang berwujud angka-angka9 ${ }^{9}$. Data yang diperoleh dalam penelitian ini adalah hasil belajar yang diperoleh dari pretest dan posttes serta 
pedoman observasi guru dan siswa selama proses pembelajaran.

Penilaian terhadap aspek atau dimensi setiap komponen belajar mengajar memerlukan sumber informasi atau sumber data dari berbagai pihak, terutama dari yang terlibat dalam kegiatan belajar mengajar. ${ }^{10}$ Sumber data pada penelitian ini adalah siswa kelas VI SD Negeri Janggi Kecamatan Karau Kuala Janggi Kecamatan Karau Kuala Kabupaten Barito Selatan dan peneliti.

Instrumen yang digunakan dalam penelitian ini adalah sebagai berikut :

\section{Tes Hasil Belajar}

Untuk evaluasi hasil belajar digunakan tes tertulis berupa pilihan tunggal dengan jumlah soal sebanyak 20 soal yang dipadukan dengan karakteristik hasil belajar. Tes hasil belajar dilakukan sebelum dan sesudah setiap siklus pembelajaran. Panduan Pengamatan

Pengamatan digunakan untuk merekam efek dari operasi terkait. Pengamatan perlu direncanakan, dan perlu didasarkan pada sikap terbuka dan kemampuan bereaksi. Pedoman observasi yang digunakan dalam penelitian ini adalah pedoman observasi bagi siswa ketika terjadi proses pembelajaran dengan menggunakan metode eksperimen dan pedoman observasi bagi guru ketika menerapkan metode eksperimen.

\section{Wawancara}

Menurut wawancara Hopkins di Wiriaatmadja, ini adalah cara untuk memahami situasi kelas dari sudut lain. Sebelum melakukan penelitian dilakukan wawancara dengan siswa untuk mengetahui permasalahan awal yang terjadi di SD Negeri Janggi Kecamatan Kalauguara Kabupaten Barito Selatan yaitu hasil belajar siswa rendah karena siswa hanya duduk. , diam, mendengarkan, mencatat dan mengingat.

Dalam penelitian ini digunakan dua teknik pengolahan data, yaitu teknologi pengolahan data uji dan teknologi pengolahan data non uji. Data yang dihasilkan oleh pedoman observasi diolah secara deskriptif untuk mengukur kualitas pembelajaran, sekaligus diolah dalam bentuk penerapan metode eksperimen, sedangkan hasil evaluasi berupa soal-soal tes dihitung melalui perhitungan sederhana..

Peneliti melakukan penjumlahan yang diperoleh siswa, kemudian dibagi dengan jumlah siswa yang ada dikelas tersebut sehingga dapat diperoleh nilai rata- rata tes.

$$
X=\sum X
$$

$\sum \mathrm{n}$

Dimana :

$$
\begin{aligned}
& \mathrm{X} \quad=\text { Nilai rata-rata } \\
& \sum \mathrm{X}=\text { Jumlah seluruh nilai siswa } \\
& \sum \mathrm{n}=\text { Jumlah siswa }
\end{aligned}
$$

Pengolahan data nontes pada penelitian ini diolah secara kualitatif. Data nontes ini diperoleh dari pedoman oservasi berupa indikator-indikator kegiatan guru dan siswa dalam proses pembelajaran. Setelah dianalisis selanjutnya data tersebut dideskripsikan dalam paparan data secara naratif. 
Skor rata-rata dari data yang dihasilkan akan dibagi menjadi empat kategori skla ordinal, yaitu baik sekali, baik, cukup, dan kurang seperti klasifikasi pada tabel 3.11 berikut :

\section{Klasifikasi Kegiatan Guru Dan Siswa}

\begin{tabular}{cc}
\hline Skor & Kategori \\
\hline 5 & Sangat Baik \\
\hline 4 & Baik \\
\hline 3 & Cukup/Sedang \\
\hline 2 & Kurang \\
\hline 1 & Sangat Kurang \\
\hline
\end{tabular}

\begin{tabular}{cc}
\hline Rentang & Kategori \\
\hline $80-100 \%$ & Sangat Baik \\
\hline $70-79 \%$ & Baik \\
\hline $60-69 \%$ & Cukup/Sedang \\
\hline $50-59 \%$ & Kurang \\
\hline $0-40 \%$ & Kurang Sekali \\
\hline
\end{tabular}

Indikator keberhasilan ini merupakan ketentuan yang sudah ada di SD Negeri Janggi Kecamatan Karau Kuala Kabupaten Barito Selatan sebagai acuan keberhasilan proses pembelajaran.

\section{Hasil Dan Pembahasan}

\section{A. Deskripsi Data}

\section{Tindakan Pembelajaran Siklus I}

a. Tahap Perencanaan

Pembelajaran pada siklus I ini terdiri atas dua pertemuan yang berdurasi $4 \mathrm{x}$ 35 menit dalam satu minggu. Materi yang akan diajarkan pada siklus satu pertemuan pertama adalah menjelaskan bahwa panas dapat dihantarkan dan menjelaskan perpindahan panas secara konveksi, radiasi, konduksi. Pada pertemuan kedua materi yang diajarkan adalah menjelaskan pengertian konduktor dan isolator panas dan menyebutkan contoh konduktor dan isolator panas. Sebelum siklus I dilaksanakan peneliti melakukan beberapa persiapan yaitu :

1) Membuat Rencana Pelaksanaan Pembelajaran (RPP) yang menggambarkan penerapan metode eksperimen

2) Membuat Lembar Kerja Siswa (LKS)

3) Menyiapakan alat peraga

4) Menyiapakan lembar observasi guru dan lembar observasi siswa untuk setiap pertemuan

5) Menyiapkan instrumen penilaian 


\section{b. Tahap Pelaksanaan}

\section{Pertemuan Pertama}

Tahap pelaksanaan untuk pertemuan pertama dilaksanakan pada hari Selasa tanggal 25 November 2017 dengan alokasi waktu 2 x 35 menit. Kegiatan pembelajaran dilakukan pada pukul 09.10 - 10.20 dengan jumlah siswa 23 orang.

\section{Pertemuan Kedua}

Secara umum pertemuan kedua memiliki kesamaan dengan pertemuan pertama, yaitu: menyusun rencana pembelajaran (RPP), menyiapkan daftar observasi untuk guru dan siswa, dan menyiapkan lembar kerja siswa yang akan digunakan. Kursus akan dilaksanakan pada hari Kamis, 27 November 2017, dengan alokasi waktu 2 x 35 menit, mulai pukul $06.30-08.40 \mathrm{WIB}$.

Hasil belajar siswa SD Negeri Janggi Kecamatan Karau Kuala Kabupaten Barito Selatan menjelaskan tentang cara perpindahan kalor, menjelaskan perpindahan kalor secara konveksi, radiasi, dan konduksi, menjelaskan pengertian konduktor dan isolator termal, serta menyebutkan contoh-contoh dengan menggunakan metode eksperimen. Konduktor dan isolator setelahnya adalah sebagai berikut.:

\section{Data Hasil Belajar Tes Siklus I}

\begin{tabular}{clcc}
\hline No & \multicolumn{1}{c}{ Hasil Tes } & Pretes & Postes \\
\hline 1 & Nilai Terendah & 20 & 45 \\
\hline 2 & Nilai Tertinggi & 70 & 95 \\
\hline 3 & Nilai Rata-rata & 39,35 & 68,48 \\
\hline 4 & Sudah memenuhi KKM & 2 & 14 \\
\hline 5 & Belum Memenuhi KKM & 21 & 9 \\
\hline 6 & Prosentase Keberhasilan & $8,70 \%$ & $60,87 \%$ \\
\hline
\end{tabular}

Berdasarkan data tabel hasil belajar tes siklus I, dapat dilihat bahwa hasil belajar pada waktu belum diterapkannya metode eksperimen pada saat pretes hanya mencapai rata-rata 39,35 dan ketika sesudah diterapkannya metode pembelajaran eksperimen terdapat peningkatan hasil belajar dengan rata-rata 68,48. Hal ini menunjukan adanya peningkatan hasil belajar siswa kelas VI SD Negeri Janggi Kecamatan Karau Kuala Kabupaten Barito Selatan sesudah diterapkannya metode eksperimen, meskipun hal ini belum memenuhi target pencapaian keberhasilan siswa yakni $90 \%$ siswa sudah tuntas.

Pada tabel data hasil belajar tes siklus I di atas juga tergambar bahwa nilai terendah pada saat prestes adalah 20 dan tertinggi 70, namun pada tes terkhir siklus terdapat peningkatan dengan perolehan terendah 45 dan tertinggi 95, siswa yang mencapai nilai KKM 14 orang. Hal tersebut menunjukan bahwa pencapaian target keberhasilan belum 
tercapai.

\section{Hasil Obsevasi Guru Siklus I}

Kegiatan guru pada saat pembelajaran diamati oleh rekan sejawat atau yang bertugas sebagai observer, penilaian oleh observer menggunakan pedoman observasi yang meliputi beberapa aspek, hasil obsevasi selama pembelajaran siklus I adalah sebagi berikut :

\section{Data Observasi Guru Pada Siklus I}

\section{No Kegiatan Guru}

\section{Penilaian}

\begin{tabular}{|c|c|c|c|}
\hline No & Keglatan Guru & $\begin{array}{l}\text { Pertemuan } \\
\text { Pertama }\end{array}$ & $\begin{array}{l}\text { Pertemuan } \\
\text { Kedua }\end{array}$ \\
\hline 1 & Menjelaskan tujuan pembelajaran & 4 & 4 \\
\hline 2 & Melakukan tanya jawab terkait materi & 3 & 4 \\
\hline 3 & $\begin{array}{l}\text { Membagi siswa menjadi } 5 \text { kelompok yang } \\
\text { terdiri dari } 4-5 \text { orang }\end{array}$ & 3 & 5 \\
\hline 4 & $\begin{array}{l}\text { Membimbing siswa mempersiapkan alat- alat } \\
\text { yang telah dibawa untuk melakukan } \\
\text { eksperimen }\end{array}$ & 4 & 4 \\
\hline 5 & $\begin{array}{l}\text { Memberikan penjelasan mengenai tahapan- } \\
\text { tahapan eksperimen yang harus dilakukan } \\
\text { siswa, termasuk yang dilarang dan } \\
\text { membahayakan }\end{array}$ & 4 & 5 \\
\hline 6 & $\begin{array}{l}\text { Membagikan LKS kepada masing-masing } \\
\text { kelompok }\end{array}$ & 3 & 4 \\
\hline 7 & $\begin{array}{l}\text { Memfasilitasi siswa untuk melakukan } \\
\text { eksperimen }\end{array}$ & 3 & 4 \\
\hline 8 & $\begin{array}{l}\text { Meminta masing-masing kelompok untuk } \\
\text { berdiskusi }\end{array}$ & 4 & 4 \\
\hline 9 & $\begin{array}{l}\text { Meminta setiap perwakilan kelompok untuk } \\
\text { menyampaikan } \quad \text { kesimpulan hasil } \\
\text { eksperimen yang telah didiskusikan }\end{array}$ & 3 & 4 \\
\hline 10 & $\begin{array}{l}\text { Memberikan kesempatan siswa bertanya } \\
\text { tentang materi pembelajaran }\end{array}$ & 2 & 4 \\
\hline 11 & $\begin{array}{l}\text { Bersama-sama siswa menyimpulkan materi } \\
\text { pembelajaran }\end{array}$ & 2 & 4 \\
\hline \multicolumn{2}{|c|}{ Jumlah } & 35 & 46 \\
\hline \multicolumn{2}{|c|}{ Prosentase tiap pertemuan } & $63,6 \%$ & $83,6 \%$ \\
\hline
\end{tabular}




\section{Hasil Obsevasi Siswa Siklus I}

Pada saat pembelajaran berlangsung, observer melakukan pengamatan terhadap siswa dalam mengikuti jalannya proses pembelajaran. Hasil pengamatan

\begin{tabular}{|c|c|c|c|}
\hline \multirow[b]{2}{*}{ No } & \multirow[b]{2}{*}{ Kegiatan Siswa } & \multicolumn{2}{|c|}{ Penilaian } \\
\hline & & $\begin{array}{l}\text { Pertemuan } \\
\text { Pertama }\end{array}$ & $\begin{array}{l}\text { Pertemuan } \\
\text { Kedua }\end{array}$ \\
\hline 1 & $\begin{array}{l}\text { Membentuk kelompok sesuai dengan } \\
\text { pembagiannya }\end{array}$ & 2 & 3 \\
\hline 2 & $\begin{array}{llll}\text { Mempersiapkan alat-alat yang telah } \\
\text { dibawa }\end{array}$ & 4 & 4 \\
\hline 3 & $\begin{array}{l}\text { Menyimak penjelasan guru mengenai } \\
\text { tahapan-tahapan eksperimen yang harus } \\
\text { dilakukan siswa, termasuk yang } \\
\text { dilarang dan membahayakan }\end{array}$ & i & 4 \\
\hline 4 & Melakukan eksperimen & 4 & 5 \\
\hline 5 & $\begin{array}{l}\text { Berdiskusi dengan kelompok masing- } \\
\text { masing }\end{array}$ & 3 & 4 \\
\hline 6 & Menyampaikan hasil diskusi & 3 & 3 \\
\hline 7 & Bertanya tentang materi pembelajaran & 2 & 3 \\
\hline 8 & $\begin{array}{l}\text { Bersama-sama menyimpulkan materi } \\
\text { pembelajaran }\end{array}$ & 2 & 4 \\
\hline Jum & & 24 & 30 \\
\hline Pros & entase tiap pertemuan & $60 \%$ & $75 \%$ \\
\hline$\overline{\text { Pros }}$ & entase tiap siklus & & \\
\hline Kate & gori & & \\
\hline
\end{tabular}

Tabel data hasil observasi siswa siklus I menunjukan presentase pada pertemuan pertama ke pertemuan ke dua, yaitu dari $60 \%$ menjadi $75 \%$. Nilai rata-rata hasil pengamatan pada siklus I adalah 67,5\% dengan kategori cukup. Hal ini belum menunjukan hasil yang maksimal, dengan demikian bahwa penerapan metode eksperimen pada setiap siswa belum optimal.

\section{d. Refleksi Siklus I}

Pembelajaran dengan menggunakan penerapan metode pembelajaran eksperimen pada materi menjelaskan bahwa panas dapat dihantarkan dan menjelaskan perpindahan 
panas secara konveksi, radiasi, konduksi, membuat siswa terlibat langsung dalam proses pembelajaran. Hal ini menuntun siswa untuk menemukan sendiri konsep yang dipelajarinya, yang menyebabkan siswa lebih aktif dalam belajar dan pembelajaranpun lebih bermakna. Namun pada pelaksanaannya, penerapan metode eksperimen pada siklus I masih terdapat kekurangan, terutama pada kegiatan siswa. Dari hasil observasi siswa terlihat kekurangannya adalah :

1. Masih ada siswa yang nilainya (hasil belajarnya) di bawah Kriteria Kertuntasan Minimum (KKM). Siswa kurang memahami materi pembelajaran ketika guru menjelaskan.

2. Kelas belum terkondisikan secara baik, karena masih ada siswa yang menolak pembagian kelompok yang telah ditentukan guru.

3. Penyampaian hasil diskusi masih didominasi oleh siswa yang pandai.

4. Siswa terlihat pasif dalam bertanya tentang materi pembelajaran yang disampaikan. Hal ini disebabkan siswa takut atau malu untuk bertanya.

Ketuntasan belajar pada siklus I hanya sebesar 60,87\%, artinya pembelajaran belum mencapai indikator keberhasilan yaitu 90\%. Pembelajaran harus ditingkatkan melalui perbaikan tindakan untuk diperbaiki pada siklus II. Adapun perbaikan tindakan yang harus dilakukan dapat dilihat pada tabel di bawah ini :

\section{Tindakan Perbaikan Siklus I}

\begin{tabular}{|c|c|c|}
\hline No & Tindakan & Perbaikan \\
\hline 1 & $\begin{array}{l}\text { Suasana kelas gaduh karena masi } \\
\text { ada siswa yang menolak pembagia } \\
\text { kelompok yang telah } \\
\text { ditentukan guru. }\end{array}$ & $\begin{array}{l}\text { hGuru harus lebih menguasai kelas dan } \\
\text { nlebih tegas terhadap siswa yang } \\
\text { menolak pembagian kelompok yang } \\
\text { telah ditentukan }\end{array}$ \\
\hline 2 & $\begin{array}{l}\text { Kegiatan diskusi lebih didominasi } \\
\text { oleh siswa yang pandai }\end{array}$ & $\begin{array}{l}\text { Guru harus lebih membimbing siswa } \\
\text { dalam kegiatan berkelompok agar } \\
\text { benar-benar bekerjasama dan yang } \\
\text { melakukan presentasi adalah anak } \\
\text { yang terlihat pasif dalam } \\
\text { kelompokya. }\end{array}$ \\
\hline 3 & $\begin{array}{l}\text { Siswa terlihat pasif dalam bertanya } \\
\text { tentang materi pembelajaran yang } \\
\text { disampaikan. }\end{array}$ & $\begin{array}{l}\text { Guru meminta setiap kelompok } \\
\text { membuat pertanyaan dan kelompok } \\
\text { lain menjawab }\end{array}$ \\
\hline
\end{tabular}




\section{Hasil Belajar Siklus II}

Hasil tes akhir pembelajaran pada siklus II Hasil sub pokok mengidentifikasi benda-benda yang termasuk konduktor panas, mengidentifikasi benda-benda yang termasuk isolator panas dan mengidentifikasi peralatan rumah tangga yang menggunakan bahan konduktor dan menidentifikasi peralatan rumah tangga yang menggunakan bahan isolator di kelas VI SD Negeri Janggi Kecamatan Karau Kuala Kabupaten Barito Selatan setelah menggunakan metode eksperimen adalah sebagai berikut :

\section{Data Hasil Belajar Tes Siklus II}

\begin{tabular}{clcc}
\hline No & Hasil Tes & Pretes & Postes \\
\hline 1 & Nilai Terendah & 20 & 55 \\
\hline 2 & Nilai Tertinggi & 75 & 100 \\
\hline 3 & Nilai Rata-rata & 56,74 & 80,65 \\
\hline 4 & Sudah memenuhi KKM & 5 & 21 \\
\hline 5 & Belum Memenuhi KKM & 18 & 2 \\
\hline 6 & Prosentase Keberhasilan & $21,74 \%$ & $91,30 \%$ \\
\hline
\end{tabular}

Dari data hasil belajar tes siklus II dapat dilihat bahwa hasil belajar pada waktu belum diterapkannya metode eksperimen pada saat pretes hanya mencapai rata-rata 56.74 dan ketika sesudah diterapkannya metode pembelajaran eksperimen terdapat peningkatan hasil belajar dengan rata-rata 80.65. Peningkatan juga terlihat pada jumlah siswa yang telah memenuhi KKM yakni 21 orang atau 91,30\% dari 23 siswa. Hal ini menunjukan adanya peningkatan hasil belajar siswa kelas VI SD Negeri Janggi Kecamatan Karau Kuala Kabupaten Barito Selatan sudah mencapai indikator keberhasilan 90\% dengan KKM setiap siswa 65

\section{Hasil Obsevasi Guru Siklus II}

Kegiatan guru pada saat pembelajaran diamati oleh rekan sejawat atau yang bertugas sebagai observer, penilaian oleh observer menggunakan pedoman observasi yang meliputi beberapa aspek, hasil obsevasi selama pembelajaran siklus II adalah sebagi berikut:

\section{Data Observasi Guru Pada Siklus II}

\section{No Kegiatan Guru}

$\begin{array}{cl}\text { Pertemuan } & \text { Pertemuan } \\ \text { Ketiga } & \text { Keempat }\end{array}$


Upaya Meningkatkan Hasil Belajar Siswa Kelas VI Sd Negeri Janggi Dalam Materi

Membandingkan Sifat Menghantar Panas

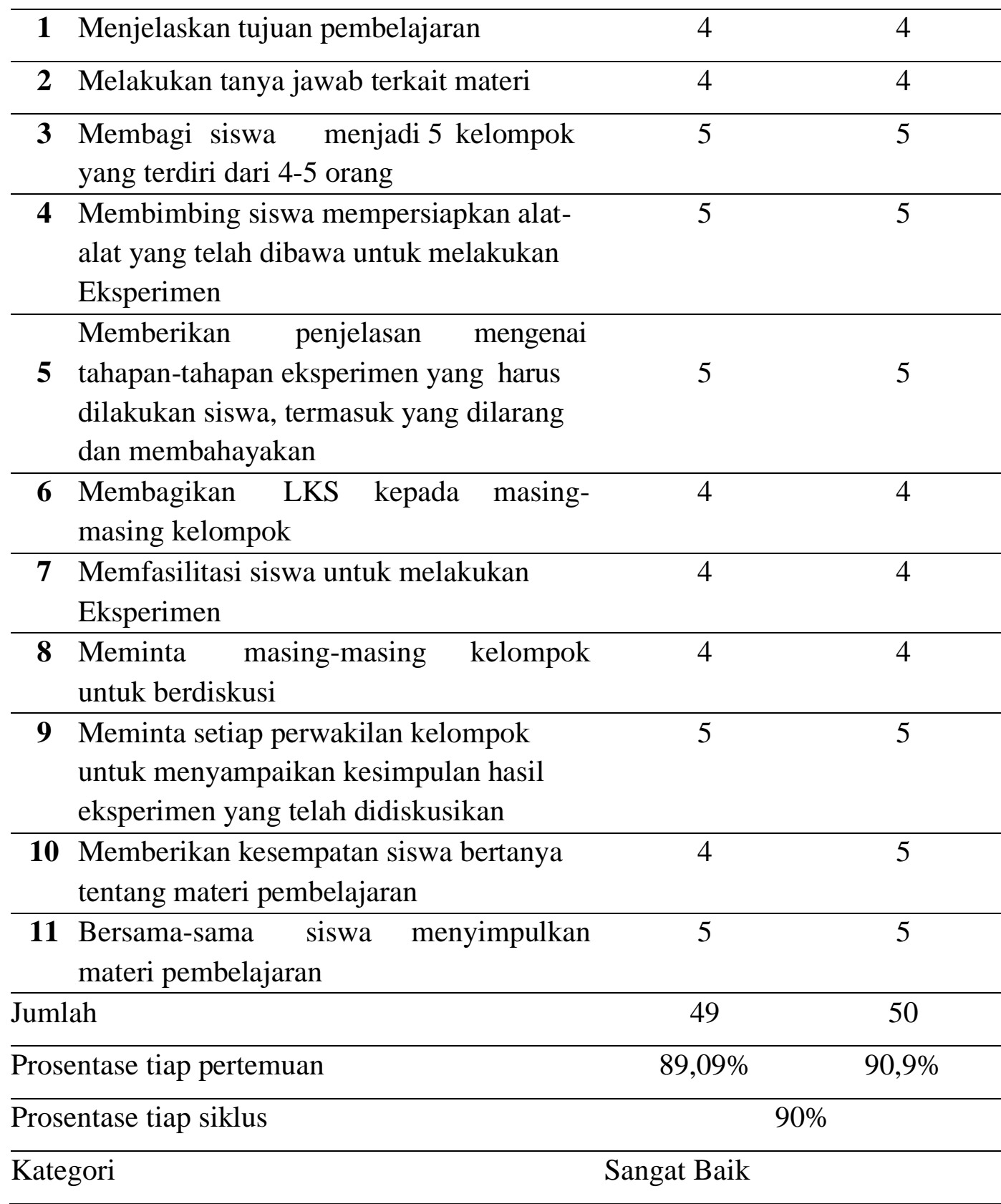

Tabel data observasi guru menunjukan bahwa rata rata presentase observer total dari hasil pengamatan terhadap guru pada siklus II mencapai angka 50 atau 90,9\% dengan kategori sangat baik. Jadi dapat disimpulkan bahwa pada siklus II guru mampu menerapkan metode eksperimen dengan baik.

\section{B. Pembahasan Hasil Penelitian}

Sebelum menggunakan metode eksperimen sifat dan konsep konduktivitas termal berbagai benda untuk tindakan pembelajaran, proses pembelajaran lebih banyak 
dipimpin oleh guru, dan pembelajaran didemonstrasikan secara lisan, sehingga siswa kurang aktif dalam proses pembelajaran. Setelah melakukan penelitian tindakan kelas yaitu melalui penerapan metode eksperimen terhadap konsep, realisasi hasil belajar siswa dipengaruhi oleh sumber belajar dan metode pembelajaran yang diterapkan dalam proses pembelajaran, dan telah terjadi perubahan. Para siswa sangat antusias dan antusias dalam belajar.

Berdasarkan hasil tes belajar siswa siklus I diketahui bahwa 9 siswa tidak mencapai KKM atau 39,13\%. Hal ini menunjukkan bahwa hasil pengujian tidak memenuhi standar integritas minimum. Hal yang sama juga terlihat dari hasil observasi siswa, masih terdapat nilai yang tergolong cukup, misalnya karena masih ada siswa yang menolak pengelompokan yang telah ditentukan, kelas tidak diatur dengan baik, dan diskusi masih berlangsung. Siswa pintar mendominasi, dan siswa masih terlihat pasif ketika bertanya. Mengenai materi pembelajaran yang diberikan. Namun, aktivitas guru yang terlihat pada daftar observasi guru sudah mendapat klasifikasi yang baik. Guru dapat memfasilitasi siswa untuk melakukan eksperimen. Sebagian besar siswa berperan aktif dalam pembelajaran, dan hanya sedikit siswa yang terlihat kurang serius saat melakukan kegiatan diskusi.

Kelemahan pembelajaran siklus I tentunya harus diperbaiki pada siklus II untuk mencapai efek pembelajaran yang diharapkan. Setelah aksi Perbaikan yang dilakukan pada Siklus II membuktikan bahwa hasil belajar siswa mengalami peningkatan. Jika 9 siswa gagal mencapai KKM pada siklus I, dan hanya 2 siswa yang gagal mencapai KKM pada siklus II, maka hasil belajar siswa memenuhi standar ketuntasan yang diharapkan yaitu 90\%. Hal ini sesuai dengan penelitian yang dilakukan oleh Sri Mulyanih bahwa metode eksperimen dapat membantu meningkatkan hasil belajar saintifik siswa. Hasil observasi guru menunjukkan adanya peningkatan dari kategori baik menjadi kategori sangat baik. Selama proses pembelajaran, aktivitas siswa juga meningkat. Pengamatan aktivitas siswa tergolong cukup pada siklus I dan meningkat menjadi kategori baik pada siklus II.

Metode eksperimen adalah metode yang ditujukan untuk mengembangkan seluruh potensi siswa.Siswa melakukan eksperimen dengan mengalami sendiri dan mencari kebenaran tentang apa yang telah dipelajarinya. Hal ini sesuai dengan pandangan Djamarah bahwa metode eksperimen adalah cara penyajian mata kuliah, dimana siswa bereksperimen dengan mengalami apa yang telah dipelajarinya. Dalam proses belajar mengajar metode eksperimen, siswa mendapat kesempatan untuk mengalami atau melakukannya sendiri, mengikuti suatu proses, dan mengamati objek, keadaan atau proses suatu hal. Pengalaman praktis membuat belajar lebih bermakna.

Secara umum penerapan metode eksperimen pada konsep perbandingan konduktivitas termal berbagai benda dapat meningkatkan hasil belajar siswa. Fakta membuktikan bahwa pada siklus berikutnya kualitas hasil belajar dan hasil observasi guru dan siswa akan meningkat. Oleh karena itu, penerapan metode eksperimen dalam pembelajaran saintifik efektif. Dalam pembelajaran semacam ini, peran guru adalah membimbing dan memotivasi, membimbing dan membimbing siswa untuk berpikir 
kritis dan analitis ketika memecahkan masalah. Siswa dapat mengaitkan hasil belajar yang telah diperoleh dengan kehidupan sehari-hari, sehingga pengetahuannya menjadi lebih bermakna. Hal ini sejalan dengan tujuan pembelajaran yaitu memberikan pengalaman belajar yang bermakna kepada siswa yang meliputi seluruh aspek kognisi, emosi dan psikomotorik.

\section{Kesimpulan}

Berdasarkan analisis terhadap data penelitian tindakan kelas yang telah dilaksanakan di SD Negeri Janggi Kecamatan Karau Kuala Kabupaten Barito Selatan dapat disimpulkan bahwa penerapan metode eksperimen dapat meningkatkan hasil belajar IPA kelas VI materi membandingkan sifat kemampuan menghantar panas dari berbagai benda. Peningkatan hasil belajar dalam proses pembelajaran IPA ini terlihat dari hal-hal sebagai berikut :

1. Perolehan nilai rata-rata hasil belajar siswa yang meningkat, yaitu 68,48 pada siklus I meningkat menjadi 80,65 pada akhir siklus II.

2. Siswa yang berhasil mencapai nilai KKM pada siklus I sebanyak 14 siswa atau 60,87\% meningkat menjadi 21 siswa atau 91,30\%.

3. Aktivitas siswa dalam proses pembelajaran setelah penerapan metode eksperimen meningkat, rata-rata aktivitas siswa pada siklus I adalah 67,5\% dengan kategori cukup meningkat menjadi $90 \%$ dengan kategori sangat baik.

4. Aktivitas guru dalam proses pembelajaran setelah penerapan metode eksperimen meningkat, rata-rata aktivitas guru pada siklus I adalah 73,6\% dengan kategori baik meningkat menjadi $90 \%$ dengan kategori sangat baik. 


\section{Bibliografi}

Arikunto, Suharsimi, dkk. Penelitian Tindakan Kelas. Jakarta: Bumi Aksara, 2006.

Arikunto, Suharsimi. Prosedur penelitian : Suatu Pendekatan Praktik. Jakarta: Bumi Aksara, 2010.

Arikunto. Suharsimi, Prosedur Penelitian. Jakarta: Rineka Cipta, edisi revisi, 2010.

Daryanto. Evaluasi Pembelajaran. Jakarta: Rineka Cipta, 2010.

Desmita. Psikologi Perkembangan Peserta Didik. Jakarta: PT Remaja Rosdakarya, 2010.

Ekawarna. Penelitian Tindakan Kelas. Jakarta: Gaung Persada, 2010.

Hamalik, Oemar. Dasar-dasar Pengembangan Kurikulum. Bandung: PT. Remaja Rosdakarya, 2009.

Hamzah, Ali. Evaluasi Pembelajaran Matematika. Jakarta: PT. Raja Grafindo Persada, 2014.

Herlanti, Yanti. Tanya Jawab Seputar Penelitian Pendidikan Sains. Jakarta: Jurusan Pendidikan IPA FITK UIN Syarif Hidayatullah Jakarta, 2008.

Immaratul Izzah, "Upaya Meningkatkan Hasil Belajar Siswa dengan Metode Eksperimen", Skripsi pada Universitas Islam Negeri Syarif Hidayatullah Jakarta,tidak dipublikasikan.

Kunandar. Langkah Mudah Penelitian Tindakan Kelas Sebagai Pengembangan Profesi Guru. Jakarta: PT. Rajagrafindo Persada.

Masitoh, "Penggunaan Metode EksperimenUntuk Meningkatkan Hasil Belajar Siswa Kelas III Pada Konsep Gerak Benda dan Energi di MI. Sirojul Athfal 1 Depok", Skripsi pada Program Studi Pendidikan Guru Madrasah Ibtidaiyah Fakultas Ilmu Tarbiyah dan Keguruan Universitas Islam Negeri Syarif Hidayatullah Jakarta, Jakarta, 2012, tidak dipublikasikan.

Maspupah, "Penerapan Metode Eksperimen Untuk Meningkatkan Hasil Belajar IPA Pada Materi Gaya Kelas V di MIS. Anwarul Hidayah", Skripsi pada Universitas Islam Negeri Syarif Hidayatullah Jakarta, tidak dipublikasikan.

Mulyasa, E. Praktik Penelitian Tindakan Kelas. Bandung: PT. Remaja Rosdakarya, 
Upaya Meningkatkan Hasil Belajar Siswa Kelas VI Sd Negeri Janggi Dalam Materi

Membandingkan Sifat Menghantar Panas

2012.

Munadi, Yudhi. Media Pembelajaran. Jakarta: Gaung Persada Press, 2012.

Nurhasanah, "Upaya Meningkatkan Hasil Belajar Siswa Pada Materi Energi

Dan

Perubahannya di Kelas IV MI Al-Arqom Melalui Metode Eksperimen", Skripsi pada Program Studi Pendidikan Guru Madrasah Ibtidaiyah Fakultas Ilmu Tarbiyah dan Keguruan Universitas Islam Negeri Syarif Hidayatullah Jakarta, Jakarta, 2012, tidak dipublikasikan.

Purwanto. Evaluasi Hasil Belajar. Yogyakarta: Pustaka Pelajar, 2013. Sagala, Syaiful. Konsep dan Makna Pembelajaran. Bandung: Alfabeta, 2012.

Sri Mulayanih, "Upaya Meningkatkan Hasil Belajar Siswa Pada Konsep Cahaya Melalui Metode Eksperimen", Skripsi pada Universitas Islam Negeri Syarif Hidayatullah Jakarta, tidak dipublikasikan.

Sudjana, Nana. Penilaian Proses Hasil Belajar Mengajar. Bandung: PT. Remaja Rosdakarya, 1992.

Sugiyono. Metode Penelitian Kuantitatif Kualitatif dan R\&D. Bandung: Alfabeta, 2012. Suprijono, Agus. Cooperative Learning. Yogyakarta: Pustaka Pelajar, 2012. Suwandi, Sarwiji. Penelitian Tindakan Kelas (PTK) dan Penulisan Karya Ilmiah.

Syah, Muhibbin. Psikologi Pendidikan. Jakarta: PT. Remaja Rosdakarya, Cet. 13, 2007. Syarifudin, dkk. Strategi Belajar Mengajar. Jakarta: Diadit Media, 2010.

Trianto. Mendesain Model Pembelajaran Inovatif-Progresif. Jakarta: Kencana Prenada Media Group, 2010.

Trianto. Mengembangkan Model Pembelajaran Tematik. Jakarta: PT. Prestasi Pustaka Karya, 2009.

Trianto. Model Pembelajaran Terpadu. Jakarta: Bumi Aksara, 2013.

Wiriaatmadja, Rochiati. Metode Penelitian Tindakan Kelas. Bandung: Remaja Rosdakarya, 2006.

Yamin, Martinis. Strstegi Pembelajaran Berbasis Kompetensi. Jakarta: Gaung Persada Press, 2006 